\title{
Article
}

http://dx.doi.org/10.11646/phytotaxa.174.2.1

\section{The genus Dennstaedtia Bernh. (Dennstaedtiaceae) in Argentina}

\author{
AGUSTINA YAÑEZ ${ }^{1}$, MARCELO D. ARANA ${ }^{2}$, GONZALO J. MARQUEZ ${ }^{1}$ \& ANTONIA OGGERO ${ }^{2}$ \\ ${ }^{1}$ Cátedra de Palinología, Facultad de Ciencias Naturales y Museo, UNLP, Paseo de Bosque s/nº 1900, La Plata, Argentina; e- \\ mail:yanez_agustina@hotmail.com \\ ${ }^{2}$ Orientación Plantas Vasculares, Departamento de Ciencias Naturales, Facultad de Ciencias Exactas, Físico-Químicas y Naturales, \\ Universidad Nacional de Río Cuarto, Ruta 36 km 601, X5804ZAB Río Cuarto, Córdoba, Argentina.
}

\begin{abstract}
A morphological analysis of the genus Dennstaedtia (Dennstaedtiaceae) from Argentina is carried out and distributional data updated. The studied species are: Dennstaedtia cicutaria, D. dissecta, D. glauca and D. globulifera. Until now, the information concerning the genus in Argentina was fragmented and incomplete. A comprehensive key to the species and detailed descriptions, distribution maps, habitat considerations, relevant notes, as well as photographs of diagnostic characters are provided for each taxon.
\end{abstract}

Key words: Argentina, Dennstaedtiaceae, distribution, flora, morphology

\section{Resumen}

Se realiza un análisis morfológico del género Dennstaedia (Dennstaedtiaceae) en la Argentina, y se actualizan los datos de su distribución. Las especies estudiadas son: Dennstaedtia cicutaria, D. dissecta, D. glauca y D. globulifera. Hasta el momento, la información sobre el género en este país resultaba fragmentaria e incompleta. Se provee una clave de las especies y descripciones detalladas, mapas de distribución, consideraciones sobre el hábitat, notas relevantes, y fotografías de los caracteres diagnósticos para cada uno de los taxones.

Palabras clave: Argentina, Dennstaedtiaceae, distribución, flora, morfología

\section{Introduction}

The genus Dennstaedtia Bernhardi (1800: 124) consists of about 45 species usually found from tropical to warm temperate regions worldwide (Kramer \& Green 1990). In the review of the genus in America, Tryon (1960) recognized 11 species. However recent studies showed that at least 20-22 taxa are present in the continent (Navarrete \& Øllgaard 2000, Rojas-Alvarado \& Tejero-Díez 2002, Mickel \& Smith 2004). Most of the American species have a primarily Andean distribution range, extending from southern United States and Mexico to southern Brazil and Argentina (Tryon \& Tryon 1982) growing in humid mountain forests, forest clearings, river banks and secondary vegetation areas.

Dennstaedtia species are characterized by long-creeping, solenostelic rhizomes, glabrous or hairy, with brownish uni-multicellular hairs. Due to the length and branching degree of the rhizome, the individuals can reach great dimensions and cover extensive areas. The fronds have 1-4 pinnate-pinnatifid blades, up to $7 \mathrm{~m}$ long and $1.5 \mathrm{~m}$ wide, glabrous to pubescent, free veins and submarginal slender to clavate apex. Many times, fronds are supported on surrounding vegetation because they reach a large size (Tryon 1964). The sori are marginal and have a double cylindrical or globular cup- or purse-shaped indusia, consisting of an inner part, which is the true indusium, and another external one formed by the reflexed leaf margin. The spores are trilete, with a verrucate, tuberculate, and reticulate ornamentation.

The taxonomic limits of the taxa are generally complicated due to the fact that, in most cases, the specimens are incomplete and the lack of diagnostic characters makes the identification of the species quite difficult (Navarrete \& Øllgaard 2000). Additionally, in some taxa, the morphology of younger specimens may differ from that of the adult ones, which can lead to misunderstandings in the identifications (Tryon 1960). 
Maxon 1938: 39. This latter species also presents spores ornamented with broad ridges, fused in reticles. Although these two taxa look very similar, they can be distinguished by three distinctive characters: the texture of the lamina on the abaxial face, which is coriaceous and bright in D. bipinnata ( $v$ s. herbaceous and opaque in D. globulifera); the trichomes on the abaxial surface which are fairly deciduous or sparse ( $v s$. persistent and abundant); and the basal segments of the pinnules of the central pinna which are opposite, not ascending and similar in size ( $v s$. alternate, ascending and varying in size). The distributional range of these two sepecies is similar. However, D. bipinnata spreads northwards up to South Florida (United States of America), being in Bolivia its southermost record. This species has not been reported yet for Argentina.

Specimens examined-: ARGENTINA. Chaco: Dpto. San Fernando, Fontana, August 1932, Meyer 644 (SI). Córdoba: Dpto. Punilla, Huerta Grande, 13 February 1903, Stuckert 12773 (CORD); Casa Bamba, 14 June 1907, Kurtz 13097 (CORD). Dpto. Santa María, Alta Gracia, 13 February 1903, Stuckert 12778 (CORD). Jujuy: Dpto. Ledesma, Parque Nacional Calilegua, 4 July 2010, Larsen \& Arana 124 (RCV, SI). Dpto. Santa Bárbara: Sierra de Santa Bárbara, 1450 m, 15 December 1962, de la Sota 2965 (SI). Misiones: Dpto. Candelaria, Santa Ana, December 1912, Rodriguez 664 (BA); Dpto. Eldorado, Ruta Provincial 17, 65 km de Dos Hermanas, camino a Eldorado, 14 October 1996, Morrone et al. 1318 (MO); Dpto. Guaraní, Ruta Provincial 15, de Ruta Nacional 14 a predio de la UNAM, $17.5 \mathrm{~km}$ de Ruta Nacional 14, 25 February 1999, Zuloaga \& Morrone 6897 (SI); Dpto. Iguazú, Parqué Nacional Iguazú, Ruta 101, 3 December 1993, Vanni et al. 3184 (LP); Dpto. Libertador General San Martín, Gruta y Salto 3 de Mayo, Puerto Rico, 12 December 1970, de la Sota et al. 6086 (LP). Salta: Dpto. Anta: Parque Nacional El Rey, 24 March 1981, Brown 1343 (MO); Dpto. Capital, Quebrada de San Lorenzo, 23 April 1994, Martínez 139 (MCNS); 23 June 1985, Palací 64 (MCNS); Dpto. Orán, Aguas Blancas, 18 July 1986, Palací 623 (LP). Tucumán: Dpto. Río Chico, entre canal 17 y Arroyo Aradito, 28 March 1942, Meyer 4378 (SI); Dpto. Tafí del Valle: Potrero de las Tablas, 20 September 1956, de la Sota 1102 (LIL).

\section{Acknowledgements}

The authors would like to express their deepest gratitude to Dr. Marta Morbelli and Dr. Monica Ponce for supporting this work and to Dr. Gabriela Giudice, Dr. Luján Luna and Dr. Juan Pablo Ramos Giacosa for their willingness to answer inquiries and provide useful tools for the analysis of the material as well as to Dr. Jefferson Prado for his valuable assistance in aspects regarding nomenclature, to the Herbaria which provided the studied specimens, and to the authorities of the provinces where the collection trips took place, by granting permits. This work was funded by grant PICT 0661 (ANPCyT).

\section{References}

Arana, M.D. \& Bianco, C.A. (2011) Helechos y licofitas del centro de la Argentina. Universidad Nacional de Río Cuarto, Río Cuarto, 85 pp.

Alston, A.H.G. (1956) The subdivision of polypodiaceae. Taxon 5: 23-25.

http://dx.doi.org/10.2307/1216940

Bernhardi, D.I.I. (1800) Tentamen alterum filices in genera redigendi. Journal für die Botanik (Schrader) 2: 121-136.

Biganzoli, F. \& Múlgura de Romero, M.E. (2004) Inventario florístico del Parque Provincial Teyú Cuaré y alrededores (Misiones, Argentina). Darwiniana 42: 1-24.

Brussa, C.A. \& Grela, I. (2005) Revisión taxonómica de Pteridophyta en Uruguay. Boletín de la Sociedad Argentina de Botánica (Suplemento) 40: 193.

Cavanilles, A.J. (1802) Descripción de las plantas que D. Antonio Josef Cavanilles demostró en las lecciones del año 1801, precedida de los principios elementales de la botánica. Imprenta Real, Madrid, 625 pp.

http://dx.doi.org/10.5962/bhl.title.32333

Ching, R.C. (1940) On natural classification of the family Polypodiaceae. Sunyatsenia 5: 201-268.

Christensen, C. (1938) Filicinae. In: Verdoorn V. (ed.) Manual of Pteridology. Nijhoff, The Hague, pp. 522-550.

Christenhusz, M.J.M., Zhang, X-C. \& Shneider, H. (2011) A linear sequence of extant families and genera of lycophytes and ferns. Phytotaxa 19: 7-54. 
Copeland, E.B. (1947) Genera Filicum. Chronica Botanica, Waltham, Massachusetts, 247 pp.

Costa Assis, F. \& Salino, A. (2011) Dennstaedtiaceae (Polypodiopsida) no estado de Minas Gerais, Brasil. Rodriguésia 62: 11-33.

De la Sota, E.R. (1977) Pteridophyta. In: Cabrera, A.L. (Ed.) Flora de la Provincia de Jujuy. Colección Científica del Instituto Nacional de Tecnología Agropecuaria 13(2): 1-275.

Ebihara, A. (2011) RbcL phylogeny of Japanese pteridophyte flora and implications on infrafamilial systematics. Bulletin of the National Museum of Nature and Science, Series B 37: 63-74.

Erdtman, G. (1960). The acetolysis method. A revised description. Svensk Botanisk Tidskrift 54: 561-4.

Farr, E.R. \& Zijlstra, G. (1996) Index Nominum Genericorum (Plantarum). Available from http://botany.si.edu/ing (accessed: May 2013).

Forster, J.R. (1786) Florulae Insularum Australium Prodromus. Gottingen, Germany, 103 pp.

Giudice, G.E., Morbelli, M.A., Macluf, C.C., Hernandez, M. \& Ruiz, A. (2006) Morphology and ultrastructure of the spores of Dennstaedtiaceae from North West Argentina. Review of Palaeobotany \& Palynology 141: 245-257. http://dx.doi.org/10.1016/j.revpalbo.2006.04.005

Hassler, E. (1928). Pteridophytorum paraguariensum et regionum argentinarum adjacentium conspectus criticus. Trabajos del Instituto de Botánica y Farmacología Facultad de Ciencias Médicas de Buenos Aires 45: 3-102.

Hieronymus, G.H. (1904) Plantae Lehmannianae in Guatemala, Columbia et Ecuador regionibusque finitimis collectae, additis quibusdam ab aliis collectoribus ex iisdem regionibus allatis determinatae et descriptae. Pteridophyta. Botanische Jahrbücher für Systematik 34: 417-582.

Holttum, R.E. (1947) A revised classification of Leptosporangiate ferns. Journal of the Linnean Society (Botany) 51: 123-158. http://dx.doi.org/10.1111/j.1095-8339.1947.tb02554.x

Holttum, R.E. (1949) The classification of ferns. Biological Reviews of the Cambridge Philosophical Society 24: $267-269$.

Jiménez, B., Knapp, S., Marín, G. \& Peña-Chocarro, M. (2000) Listado preliminar de plantas vasculares de la Reserva Natural del Bosque Mbaracayú, Paraguay. Rojasiana 5: 141-277.

Kaulffus, G.F. (1824) Enumeratio filicum quas in itinere circa terram. Lipsiae, $300 \mathrm{pp}$.

Keating, R.C. (1968) Trends of specialitation in the stipe anatomy of Dennstaedtia and related genera. American Fern Joural 58: 126140.

Kieling-Rubio, M.A. \& Windisch, P.G. (2002) O género Dennstaedtia Moore (Dennstaedtiaceae, Pteridophyta) no Estado do Rio Grande do Sul, Brasil. Pesquisas Bot. 52: 185-194.

Kramer, K.U. \& Green, P.S. (1990) Pteridophytes and Gymnospermes. In: Kubitzki, K. (Ed.) The Families and Genera of Vascular Plants. Vol. 1. Springer-Verlag, Berlin, pp. 1-404.

Legrand, C.M.D.H. \& Lombardo, A. (1958) Flora del Uruguay. I. Pteridophyta. Museo Nacional Historia Natural, Montevideo, República Oriental del Uruguay, pp 1-67.

Lellinger, D.B. (2002) A modern multilingual glossary for taxonomic pteridology. Pteridologia 3: 1-263.

L'Héritier de Brutelle, C.L. (1788) Sertum Anglicum. Paris (Facsimile edition with introductory notes. Pittsburg, 1963).

Lorscheitter, M.L., Ashraf, A., Windisch, P. \& Mosbrugger, V. (2002) Pteridophytes spores of Rio Grande do Sul, Brazil: Part IV. Paleontographica Abteilung B 263: 1-159.

Looser, G (1932) Ensayo sobre la distribución geográfica de los helechos chilenos. Revista Chilena de Historia y Geografía 69: 162198.

Looser, G. (1971) El género Dennstaedtia (Filices) en Chile. Anales del Museo de Historia Natural de Valparaiso 4: 53-61.

Lovis, J.D. (1977) Evolutionary patterns and proceses in ferns. Advances in Botanical Research 4: 29-415.

Marquez, G., Giudice, G.E. \& Ponce, M. (2006) Pteridofitas de la Reserva "Valle del Arroyo Cuñá Pirú” (Misiones, Argentina). Darwiniana 44: 108-126.

Martinez, O.G., de la Sota, E.R. \& Novara, L.J. (2000) Dennstaedtiaceae. Aportes Botanicos de Salta-Serie Flora 6(7), 1-13.

Maxon, W.R. (1938) Fern Miscellany-IV. Proceedings of the Biological Society of Washington 51: 33-40.

Mehra, P.N. (1961) Chromosome numbers in Himalayan ferns. Research Bulletin of the Panjab University (ns) 12: 139-164.

Mettenius, G.H. (1864) Prodomus Florae Novo-Granatensis ou Énumération des plantes de la Nouvelle-Grenade. Filices. Annales des Sciences Naturelles (Botanique) 5(2): 193-271.

Mickel J.T. (1973) The classification and phylogenetic position of the Dennstadtieaceae. In: Jeremy, A.C., Crabbe, J.A. \& Thomas, B.A. (Eds.) The phylogeny and classification of the ferns. Academic Press for The Linnean Society of London, London, pp. $135-144$.

Mickel, J.T. \& Smith, A.R. (2004) Pteridophytes of Mexico. Memoirs of the New York Botanical Garden 88: 1-1055.

Moore, T. (1857) Index Filicum: A Synopsis, with Characters, of the Genera, and an Enumeration of the Species of Ferns, with Synonymes,

References (Vol. 1). Pamplin. London, 396 pp.

http://dx.doi.org/10.5962/bhl.title.19640

Moore, T.M. (1861) Index Filicum 2. Pamplin, London, 287 pp. 
Moran, R.C. \& Riba, R. (1995) Psilotaceae a Salviniaceae. In: Davise, G., Sousa, S. M. \& Knapp, S. (Eds.) Flora Mesoamericana, Vol. 1. Universidad Autónoma de México, DF, 470 pp.

Morbelli, M.A. (1980) Morfología de las esporas de Pteridophyta presentes en la región fuego-patagónica República Argentina.Opera Lilloana 28: 1-138.

Navarrete, H. \& Øllgaard, B. (2000) The fern genus Dennstaedtia (Dennstaedtiaceae) in Ecuador, new characters, new species and a new combination. Nordic Journal of Botany 20: 319-346. http://dx.doi.org/10.1111/j.1756-1051.2000.tb00747.x

Nayar, B.K. (1970) A phylogenetic classification of the homosporous ferns. Taxon 19: 229-236. http://dx.doi.org/10.2307/1217958

Peña Chocarro, M., Jiménez, B., Marín, G. \& Knapp, S. (1999) Checklist of the pteridophytes of the Mbaracayú Forest Nature Reserve, Paraguay. Fern Gazette 15: 221-259.

Pichi Sermolli, R.E.G. (1970) A provisional catalogue of the family names of living Pteridophytes. Webbia 25: $219-297$. http://dx.doi.org/10.1080/00837792.1970.10669935

Pichi Sermolli, R.E.G. (1977) Tentamen Pteridophytorum genera in taxonomicum ordinem redigendi. Webbia 31: $313-512$. http://dx.doi.org/10.1080/00837792.1977.10670077

Plumier, C. (1705) Traité des fougeres de l'Amerique. De l'Imprimerie Royale, Paris, 500 pp.

Poiret, J.L.M. (1804). Encyclopédie méthodique. Botanique. Tome 5, pt. 2. Agasse, Paris, 748 pp.

Ponce, M.M. (1996) Pteridophyta. In: Zuloaga, F.O. \& Morrone, O. (Eds.) Catálogo de las Plantas Vasculares de la República Argentina I: Pteridophyta, Gymnospermae y Angiospermae (Monocotyledoneae). Monograph in Systematic Botany from the Missouri Botanical Garden 60: 1-79.

Ponce, M.M., Prado, J. \& de la Sota, E.R. (2008) Dennstaedtiaceae. In: Zuloaga, F.O., Morrone, O. \& Belgrano, M.J. (Eds.) Catálogo de las Plantas Vasculares del Cono Sur, (Argentina, Sur de Brasil, Chile, Paraguay y Uruguay). Monographs in Systematic Botany from the Missouri Botanical Garden 107: 26-31.

Prantl, K. (1892) Das System der Farne. Arbeiten aus dem Königl. Botanischen Garten zu Breslau 1:1-38.

Presl, K.B. (1836) Tentamen pteridographiae seu genera filicacearum. Typis filiorum Theophili Haase, Praga, 290 pp.

Proctor, G.R. (1977) Pteridophyta. In: Howard, R.A. (Ed.) Flora of the Lesser Antilles, vol. 2. Arnold Arboretum, Jamaica Plain, Massachusett, 414 pp.

Rojas-Alvarado, A.F. \& Tejero-Díez, J.D. (2002) Una especie nueva de Dennstaedtia (Filicales: Dennstaedtiaceae) para México. Revista de Biología Tropical 50: 1007-1012.

Schuettpelz, E. \& Pryer, K.M. (2007) Fern phylogeny inferred from 400 leptosporangiate species and three plastid genes. Taxon 56: $1037-1050$. http://dx.doi.org/10.2307/25065903

Schuettpelz, E. \& Pryer, K.M. (2008) Fern Phylogeny. In: Ranker, T.A. \& Haufler C.H. (Eds.) The Biology and Evolution of ferns and Lycophytes. Cambridge Univ. Press., pp. 395-416. http://dx.doi.org/10.1017/cbo9780511541827.016

Schwartsburd, P.B. (2010) Lista de Espécies da Flora do Brasil. Jardim Botânico do Rio de Janeiro. Available from http://floradobrasil. jbrj.gov.br/jabot/listaBrasil/ConsultaPublicaUC/BemVindoConsultaPublicaConsultar.do (accessed: 11 July 2013).

Scopoli, J.A. (1760) Flora Carniolica. Trattner, Viena, 608 pp.

Sehnem, A. (1972) Pteridáceas. In: Reitz, R. (Ed.) Flora Ilustrada Catarinense I (PTER), Herbario Barbosa Rodriguez, Itajaí, pp.: 1244.

Smith, A.R., Pryer, K.M., Schuettpelz, E., Korall, P., Schneider, H. \& Wolf P.G. (2006) A classification for extant ferns. Taxon 55: 705-731. http://dx.doi.org/10.2307/25065646

Stevenson, D.W. (1976) Shoot ápex organization and origin of the rhizome-borne roots and their associated gaps in Dennstaedtia cicutaria. American Journal of Botany 63: 673-678.

Stolze, R.G. (1981) Ferns and fern allies of Guatemala, Part II. Polypodiaceae. Fieldiana Botany 6: 1-522.

Swartz, O. (1801) Genera et Species Filicum. Journal für die Botanik: 1-487.

Thiers, B. (2014) Index Herbariorum. I. The Herbaria of the World. Available from http://sweetgum.nybg.org/ih/ (accesed: 11 March 2014).

Tressens, S.G., Keller, H.A., \& Revilla, V. (2008) Las plantas vasculares de la reserva de uso múltiple Guaraní, Misiones (Argentina). Boletín de la Sociedad Argentina de Botánica 43, 273-293.

Tryon, R.M. (1960) A review of the genus Dennstaedtia in América. Contributions from the Gray Herbarium 187: $23-52$.

Tryon R.M. (1964) The ferns of Peru. Polypodiaceae (Dennstaedtieae to Oleandreae). Contributions from the Gray Herbarium 194: $1-253$. 
Tryon, R.M. \& Tryon, A.F. (1982) Ferns and allied plants with special reference to tropical America. Springer-Verlag, New York, 857 pp.

Tryon, R.M. \& Stolze, R.G. (1989) Pteridophyta of Peru. II, 13. Pteridaceae - 15. Dennstaedtiaceae. Fieldana Botany New Series 22: 1-128.

Tryon, R.M. \& Lugardon, B. (1991) Spores of the Pteridophyta: surface, wall structure, and diversity based on electron microscope studies. Springer-Verlag, New York, 648 pp.

Vareschi, V. \& Lasser, T. (1968). Flora de Venezuela. Vol. I. Helechos. Instituto Botanico, Talleres Graficos Universitarios, Caracas, 1039 pp.

Walker, T.G. (1973) Evidence from cytology in the classification of ferns. In: Jeremy, A.C., Crabbe, J.A. \& Thomas, B.A. (Eds.) The Phylogeny al Classification of the ferns. Academic Press for The Linnean Society of London, London, pp. 91-110.

Willdenow, C.L. (1810) Species Plantarum. Editio quarta. Vol. 5: i-xliv + 1-542. G. C. Nauk, Berlin.

Wolf, P.G., Soltis, P.S. \& Soltis, D.S. (1994) Phylogenetic relationships of dennstaedtioid ferns. Evidence from rbcL sequences. Molecular Phylogenetics and Evolution 3: 83-392.

Wolf, P.G. (1995) Phylogenetic Analyses of $r b c L$ and Nuclear Ribosomal RNA Gene Sequences in Dennstaedtiaceae. American Fern Journal 85: 306-327.

http://dx.doi.org/10.2307/1547812

Yañez, A., Marquez, G.J., \& Morbelli, M.A. (2012) Primer registro de Dennstaedtia dissecta (dennstaedtiaceae) para la flora Argentina. Darwiniana 50: 332-338. 